\title{
Students' perceptions of global citizenship at a local and an international school in Israel
}

\begin{abstract}
This article reports on a comparative study revealing students' perceptions and conceptualizations of global citizenship in two different educational settings in Israel, a country facing long lasting violent conflict between Jewish Israelis and Palestinians. Jewish Israeli students attending a public Israeli school and students at an international school located in Israel catering to a Jewish, Palestinian, and international clientele participated in this explorative qualitative study, which involved in-depth interviews and focus groups with students from both a local and an international school. Four major themes emerged through our analysis: (1) inclusion and exclusion criteria for the term 'global citizen'; (2) the tensions between the different dimensions of global citizenship; (3) schools' agency in educating towards global citizenship; and (4) the role of global citizenship in conflict resolution. The main contribution of this study lies in its comparative perspective that enables us to discern the different impacts of the Israeli context on the perceptions of global citizenship in different types of schools.
\end{abstract}

Keywords: Global Citizenship Education, students, Israel, schools' agency, conflict ridden societies, soft global citizenship education. 


\section{Introduction}

The notion of citizenship as depicted within classrooms in many countries shifted in recent years from a focus on construction of unitary national identity to presentation (at least in theory) of more cosmopolitan ideas, including protection of universal human rights and the rights of marginalized groups, such as religious minorities and women (Bromley, 2009). Scholars argue that "national identity is giving way to multiple and transnational civic affiliations" (Myers, 2010: 483). In particular, while once schools were entrusted mainly with the responsibility of promoting patriotic values in students (who comprise part of what Anderson [1991] coined as the national 'imagined community'), a greater number of schools and governments today are adopting a cosmopolitan narrative that includes global citizenship and related terms (Dill, 2013; Reilly \& Niens, 2014). Moreover, as claimed by Myers (2016), in similar to the way that globalization in education had been driven by free market, competition and neoliberal logic, global citizenship education many times "wrapped up in a market oriented skill set that prepares students for achievement in high stakes testing and global competitiveness" (p. 3) and thus actively promoted by the states.

Alongside schools' and policymakers' increasing acknowledgement of global citizenship as a desired educational outcome, globalization itself contests the traditional national citizenship model in two opposite directions (Myers, 2010): from within the nation state, through the assertion of the rights and autonomy demands of various social and ethnic groups; and from outside, as individuals increasingly adhere to global affiliations that extend beyond the particular nation (Harpaz, 2013). This process is particularly intriguing in heterogeneous societies and in conflict situations, where conflictual identities' representations meet (Yemini. Kuperberg, \& Bar Nissan, 2014).

This study is based largely on the previous studies of Jacqueline Reilly and Ulrike Niens groups (Gill \& Niens, 2014; Niens \& Chastenay, 2008; Niens, OConnor, \& Smith, 2013; Niens \& Reilly, 2012; Reilly \& Niens, 2014) investigating the perceptions of global citizenship among students in conflict and post-conflict societies (specifically in North Ireland), as well on John Myers' works with students in particular educational settings is US (Myers, 2006, 2010; Myers \& Zaman, 2009). As Myers notes (2010: 484): “[u]nderstanding adolescents' cognition about global citizenship is significant because it is a fundamentally contested concept that has implications for how they will exercise citizenship in the future." 
The present study further promotes empirical research on this subject and applies qualitative methodologies of in-depth interviews and focus groups to investigate the subjective perceptions of global citizenship among students in Israel - a society situated in 'intractable conflict' between Jewish Israelis and Palestinians (Bar-Tal, 2000). It was acknowledged that this issue has received almost no scholarly attention in the Israeli context (Goren \& Yemini, 2017b), and specifically, students' perceptions of global citizenship have not been investigated (Goren \& Yemini, 2016; 2017a). Here, we compare student perceptions at two high schools in central Israel: (1) an international school following International Baccalaureate (IB) curricula with an inclination towards peace education that caters to Israeli students, a relatively large population of Palestinian students, and an international student population from all over the world; and (2) a neighboring public Israeli school following the local curriculum and catering to high-achieving students, generally from a socio-economically advantaged population. This research setting allows us not only to explore the perceptions of global citizenship in another conflict-ridden region, but also to better articulate the meaning of educational context and internationalized settings (in particular, schools following IB curricula) that might influence the shaping of such perceptions.

Global citizenship education remains an untouched concept in Israel, whose education system is undergoing a move towards nationalistic and locally oriented curricular contents (Goren \& Yemini, 2017a; Yemini, 2014). Studies of the Israeli civics curriculum have shown that the increasing attempts to legitimize Israel's self-definition as the Jewish State have left little room to discuss civics issues on a global level (Cohen 2017; Ichilov, Salomon, \& Inbar, 2005; Nasser \& Nasser, 2008; Pinson, 2007). It was intriguing, therefore, to conceptualize students' perceptions of this subject, given Israeli's unique situation as a country with a developed globally oriented high-tech sector and globalized higher education sector (Yemini \& Fulop, 2015), which also faces profound ethnic, religious, cultural, and ideological cleavages that foster nationalistic and locally oriented schooling (Neuberger, 2007).

We followed the research questions Myers (2010) raised in his study of high-achieving Pennsylvania students' perceptions of global citizenship, adding specific context-related issues relevant to our study. Specifically we investigated the following questions: (1) what patterns of meanings can be identified in the students' thinking about global citizenship and its complexities in each of the schools? And (2) how do students understand the relationship between national 
and global citizenship within the unique context of a conflict-ridden society? We address these questions with the aim of capturing students' personal perceptions on this subject, while acknowledging that global citizenship as a concept was rarely operationalized for research (Myers, 2010).

Building on the approaches and typologies of Oxley and Morris (2013), Veugelers (2011), and Stein (2015) (as detailed in the next section), we choose to develop an operationalization of the global citizenship concept in situ, by listening to the students' voices and interpreting their perceptions and values, rather than commencing the study with a strict definition. Thereby, we enable the students themselves to illuminate the global citizenship concept as per their own perceptions, thus serving as our primary data source. Working inductively, we nevertheless acknowledge and reflect on our own (Goren \& Yemini, 2017c) and our informants' prejudices and ethnocentric outlook towards the Westernized way of living and engaging (as per Andreotti, 2011). By investigating the similarities and the differences between different groups' perceptions and juxtaposing the resulting formulations with the ones offered in the contemporary scholarship, we propose several understandings that contribute to the conceptualization of this complex construct and assist the educators and curricular developers with insights from the field.

\section{Context}

\section{Global citizenship education}

Notably, no consensual definition of global citizenship exists (Oxley \& Morris, 2013; Schattle, 2008) although global citizenship education (GCE) has been acknowledged by the USESCO as a central tenet in the 2030 sustainable development goals. UNESCO (2014) defined global citizenship education (GCE) as a goal that aims “... to empower learners to engage and assume active roles both locally and globally to face and resolve global challenges and ultimately to become proactive contributors to a more just, peaceful, tolerant, inclusive, secure and sustainable world."

Oxley and Morris (2013) offer a useful typology of GCE by creating an integrative model of previous conceptualizations (see: Osler \& Starkey, 2003; Veugelers, 2011). Their typology categorizes conceptions of global citizenship as either cosmopolitan or advocacy modes. While cosmopolitan conceptions refer to identification, global consciousness, and understanding of global relations, advocacy-based conceptions focus more on global problem solving. Each 
category Oxley and Morris (2013) suggest is sub-divided into particular aspects of global citizenship - covering moral, political, cultural, environmental, and other issues. As in previous typologies (Veugelers, 2011; Dill, 2013), here also the links between citizenship education and global citizenship education are reinforced through attention to global human rights (Gearon, 2016) and environmental education (Jimenez, Lerch, \& Bromley, 2017). Andreotti (2006) offers a broad conception of GCE, differentiating between soft and critical GCE. While soft GCE could be defined as education about global citizenship (providing students with an understanding of the world and cultural tolerance), critical global citizenship requires a deeper engagement with and unlearning of common understandings (in other words, education that copes with the worlds' complexities and multidimensionality). According to Arshad-Ayaz, Andreotti and Sutherland (2017: 21) soft GCE: "...proposes the idea of a common humanity heading toward a common "forward", in which a privileged few are responsible for the many in a quest to achieve 'modernity' and 'progress' for all'. Critical GCE, which Andreotti (2010) later developed into post-critical and post-colonial GCE, provides students with the skills to reflect upon and engage with global issues involving conflict, power, and opposing views; to understand the nature of colonial, liberal, and western assumptions; and to strive for change.

Stein (2015) maps the existing discourses that define GCE and while concentrating on critical angle of the discourse, suggests a framework differentiating among entrepreneurial, liberalhumanist, and anti-oppressive dimensions, proposing also the so called 'incommensurable position'. While entrepreneurial GCE highlights the students' skills for success in a global market place within neoliberal logic, the liberal-humanist dimension addresses the concepts of intercultural understanding, empathy and global human rights. According to Arshad-Ayaz, Andreotti and Sutherland (2017) such dimensions of GCE are heavily inclined towards Eurocentric point of view, undermining the prolonging effects of colonialization and existing power relations. Thus, the anti-oppressive dimension focuses on identification and analysis of the existing power relations and preaches towards actions leading to re-distribution of power and equality in resources. Stein (2015) also proposes 'incommensurable' dimension that promotes the questioning of the concept of GCE while "points to epistemic racism inherent in the articulations of GCE that results in an absence of other perspectives, voices, and positions especially from the colonized populations and knowledge systems" (Arshad-Ayaz, Andreotti, \& Sutherland, 2017:22). 
Both academic and political critics have targeted the concept of global citizenship, arguing that it could weaken nation-states by providing citizens with an alternative identity (Bowden, 2003) or that the concept itself is moot in absence of any global governance for the global society it promotes (Bates, 2012). Critics emphasizing global citizenship's underlying perils note the possibility that like globalization, global citizenship could ultimately benefit the world's elite classes and higher echelons while excluding others (Goren \& Yemini, 2017b; Bates, 2012; Yemini, 2014a; 2015), thereby deepening social inequality and gaps (Gardner-McTaggart, 2016; Roman, 2003). Critiques of the term often refer to its ambiguity and to both latent and explicit Eurocentric assumptions that are considered to be embedded in its core (Andreotti, 2006). Moreover, Stein (2015) for example suggests to question the basic concepts of 'education', 'global' and 'citizenship' as concepts that have been traditionally bounded to the way the West understands the social realm, omitting competing views and silencing the communities with less voice (in terms of language, gender, resources, locations and culture). As Stein (2015) articulates: "According to this position, the claims to universalism made by the West are only made possible through the enactment of symbolic and material violence upon its Others, particularly through the demand that the latter be made coherent and legible through some measure of sameness or out of tokenistic appreciation.” (p. 248). Stein (2015) calls for the "denaturalizing assumptions about Western supremacy and the way these assumptions order the world“ (p. 248). In that sense, the whole essence of GCE should be put into question, while providing the youth with the tools to critically engage with the concepts and contexts of GCE.

\section{Global citizenship education in conflict-ridden societies}

Countries engaged in international conflict may be especially concerned about the possible perils of global citizenship, and they may forego global citizenship education (GCE) for fear that it may threaten their sovereignty (Davies, 2008; Niens \& Reilly, 2012). For these reasons, scholars like Davies (2008) and Gill and Niens (2014) place particular emphasis on the benefits of GCE in conflict-ridden national landscapes. These scholars' main claim is that global citizenship 
education could create a common ground of tolerance and understanding that may bridge over differences and enable dialogue.

Nevertheless, in cases of countries situated in a prolonged conflict, GCE found to be perceived especially controversial due to the pressures to instill the desired national narrative through education of the country's youth (Goren \& Yemini, 2017a; Quaynor, 2015). In Northern Ireland, for example, teachers reported difficulty teaching the GCE curriculum since no consensus exists regarding the issues it covered (Reilly and Niens 2014). In Liberia, GCE was described as secondary to the need for nation-building through the education system and the civics curriculum in particular (Quaynor 2015). As Reilly and Niens note (2014:55), “[f]or teachers in post-conflict societies, additional difficulties [in incorporating global citizenship] arise, whether they focus on the local level, where divergent identities need to be negotiated, or on the global level, where divergent North/South agendas and Western values need to be analyzed." Nevertheless, GCE has been acknowledged for its potential role in reconciliation and peace education, based on common values such as universal human rights, empathy and intercultural sensitivity (Gaudelli, 2016; Monaghan \& Spreen, 2016).

\section{Global citizenship education in international schools}

Traditionally, international schools cater to a diverse student population, offering internationallyrecognized diplomas - most prominent among these is International Baccalaureate (IB) of the International Baccalaureate organization (IBO) (Tarc \& Tarc, 2015). In practice, however, a huge variety of international schools with different underlying aims serve different clienteles (Bates, 2012; Tamatea, Hardy, \& Ninnes, 2008).

International schools present a unique context for GCE, since they are not required to foster any particular sense of national identification among their students. These schools often incorporate the development of global-mindedness or global citizenship into their mission statements, implying that they prepare their students to become members of a global society instead of or in addition to identifying with a specific nation (Doherty, 2009; Hayden \& Wong, 1997; Tarc \& Tarc, 2015). Indeed, the high diversity within the student body in many international schools requires that the schools help their students mediate between their multiple identities (those forged at home and those developed within the school) (Resnik, 2016), thereby placing international schools in a role similar to that of schools in multicultural societies, which 
are also required to mediate a plethora of identities (Banks, 2008). Yet despite the common perception of international schools as enabling mobility and meeting the 'Other,' thus inevitably developing cosmopolitan citizens, Brunold-Conesa (2010) provides evidence of variations in the global orientation of international school programs and notes that global orientations do not automatically emerge from merely placing students from different backgrounds in one school. Andreotti, Biesta, and Ahenakew (2015:253) claim that mobility and the experience of "cultural otherness and difference is neither a necessary nor a sufficient condition for responsible engagement with the 'Other', and sometimes can actually hinder such engagement.”

\section{Global citizenship education in the Israeli context}

This article focuses specifically on Israel, where GCE remains excluded from the official state curriculum (Goren \& Yemini, 2017a; Hanna, 2015). The traditional Israeli civics program (which takes roots in curricula published before the state's formation) makes almost no mention of the term; nor do any recent policy reforms. Yet the Israeli civics and geography curricula do include topics related to globalization and human rights (Avnon, 2013). However, the absence of GCE in school curricula or education policies may not demonstrate that Israelis are unaware of this concept or that it has not penetrated the national discourse; rather, it may hint at nationalistic perceptions that abide within the Israeli education system, as in those of other conflict-ridden societies (Banks, 2008).

As opposed to GCE, civics education comprises a highly studied sub-field in Israeli education research and often enters the public discourse (see the literature review in Avnon, 2013). The Israeli civics curriculum instituted prior to the declaration of the Jewish state is based on Israel's self-definition as a Jewish democratic state (Alexander, Pinson, \& Yonah, 2012; Pinson, 2007). This dual definition (Jewish and democratic) yielded numerous conflicts regarding the goals of civics education, which played out in the development of curricula and textbooks. Ichilov, Solomon, and Inbar (2005) demonstrate that the changes in the civics curriculum from the periods preceding the declaration of Israel's statehood until recently reflect a constant interplay between the Jewish and democratic definitions of the state, with each tenet overshadowing the other at times. 
Recent studies (Goren \& Yemini, 2016; 2017a;b) address teachers' perceptions of GCE in Israel, providing a glimpse into the obstacles and opportunities of teaching GCE in a conflictridden society. Specifically, they reveal that the teachers consider the Palestinian-Israeli conflict a barrier to GCE, either directly (by creating a survival urgency that overshadows any desire to socialize students into global society) or indirectly (by encouraging nationalism, stressing the demographic threat minorities pose to the state, and complicating the notion of human rights). Additionally, and perhaps consequently, findings indicate that teachers often form instrumental and pragmatic notions of global citizenship, which have been widely criticized in the literature (Goren \& Yemini, 2017b; Stein, 2015). Given the focus on teachers, the research on GCE in Israel must be expanded to address also the perceptions of students as main stakeholders in the learning process. Moreover, following the call of Niens and Reilly (2012) for more empirical studies of the global citizenship concept in conflict-ridden societies, Israel comprises a highly relevant case study to examine perceptions of global citizenship. Our access to the students at one of the few international schools located in Israel and the comparative focus applied here (between a local Israeli school and an international school) offer us profound insights into various nuances in students' perceptions of GCE and its implications.

\section{Research design}

This exploratory study applies a qualitative approach. The population includes students from two secondary schools in Israel: an international school following the IB curriculum and an affluent public secondary school located in the country's center, catering mostly to highachieving students. The included school is the only state international school in Israel following the IB curriculum, enabling limited but highly specific data collection; given this study's novel scope of investigation and approach, such data provides valuable insights into students' perceptions in this unique educational context. Specifically we investigated the following questions: (1) what patterns of meanings can be identified in the students' thinking about global citizenship and its complexities in each of the schools? And (2) how do students understand the relationship between national and global citizenship within the unique context of a conflictridden society?

We chose the participating schools through purposeful sampling, following our interest in this unique new international school that opened up in Israel in 2014. We choose to explore 
students' opinions there, comparing them with a local school that shares some of the basic school characteristics (i.e., location, student socio-economic status, and organizational structure). Data collection was conducted in two phases: first, semi-structured, extensive interviews were held with three students from each of the schools, in order to characterize the main issues that would be investigated in depth later and to gain some insights into the differences between the groups. We also used previous studies of teachers' perceptions on GCE (Goren \& Yemini, 2016; 2017a) to shape our initial understanding of how GCE studied in those two contexts. Understanding the teachers' views of GCE in both schools (Goren \& Yemini, 2016, 2017a) allowed us to capture the nuances in students' responses, providing additional comparative angle to this study. The second phase consisted of two focus groups for each school (four focus groups in total), which lasted approximately two hours each and involved eight students each (32 students in total, participating in four focus groups); participants were randomly selected and had agreed to participate in this study. No student participated in both a personal interview and a focus group, in order to avoid overlap and bias in the findings. All interviews and focus groups were recorded and transcribed. The group sessions were also videotaped, so as to assist in the transcription and to capture non-verbal dynamics. The interviews and the focus groups followed the research questions, asking the students to define national and global citizenship, investigating their perceptions and views regarding this issue, and prompting them to express their experiences regarding their schools' approach towards GCE. Focus groups were held as an open discussion (as per Puchta \& Potter, 2004), touching on issues that are common to all participants. The discourse was developed through a rational conversation (as per Bauer \& Gaskell, 2011). This method provided us exposure to the effects of group discussion in a way that cannot be uncovered through questionnaires, a personal interview, or on-site observation (Bloor et al., 2001; Fren, 2001). Notably, in our initial stage of individual interviews, we found that students provided us with limited discussion opportunities and were relatively closed in their will and ability to elaborate on the subject; the decision to conduct focus group to ignite and shape the discussion in a more multidimensional manner (as per Fren, 2001) indeed proved fruitful. The findings reported in this paper comprise part of a larger study including observations of lessons and school ceremonies, in-depth interviews with teachers at both schools, and analysis of the schools' websites. We rely here only on the findings from our direct investigation of students' 
perceptions (expressed in interviews and focus groups), but place our resultant understandings in the context of additional supportive sources of information.

The qualitative data analysis techniques we applied involved inductive analysis (Marshall \& Rossman, 2014; Miles \& Huberman, 1994) including coding, organizing, and reorganizing the data through development of matrixes and models. We first completed thematic summaries detailing salient themes from each interview (as per Glaser \& Strauss, 1967). We developed inductive codes based on our initial thematic summaries and deductive codes drawn from the literature. Here also we were able to compare the findings with teachers' views (Goren \& Yemini, 2016; Yemini \& Dvir, 2016). Using matrices and analytic memos, we conducted crosscase analysis to identify emerging themes across data sources (as per Miles \& Huberman, 1994). Our analytical process was iterative and spiral, while applying the key steps of data coding: reducing the data into meaningful segments, combining the codes into broader categories, and displaying the core data (as per Creswell, 2007). This method enables demonstration of participants' point of view while simultaneously aiming towards an interpretive dimension, which comprises the core of content analysis. To triangulate our findings and increase the study's truthfulness, we performed two focus group at each school, backed up by the interviews with individual students.

This study has several limitations, mostly related to its limited scope comparing two specific schools, which precludes far-reaching conclusions that could be applied to an array of contexts. However, the patterns that emerged from our findings could certainly be identified or cross-checked in other schools and environments. As such, this exploratory study provides a solid framework for future research involving the conception and practice of global citizenship in different educational contexts, especially focusing on students as proactive (and often neglected) partners in the learning process.

\section{Findings and analysis}

The purpose of this study was to explore diverse students' vocabularies of global citizenship in the context of a conflict-ridden society, through a qualitative, bottom-up, comparative approach. We present our findings arranged according to the emerged themes, detailing the students' perceptions at each school as they were captured and analyzed through focus groups and interviews. For each section, we then discuss the findings juxtaposed with 
definitions and conceptualization of global citizenship in current scholarship, as well as in constant comparison between the perceptions of students at the local versus international school.

\section{Who can be a global citizen?}

Our first quest was to uncover patterns of meanings in the students' thinking about global citizenship and its complexities in each of the schools. In this study, we were requesting that the students present their perspectives and then reflect on the concept of 'citizenship' and on the term 'global citizenship.' Considering the huge differences that were found in the perception of local versus international school teachers' perceptions of GCE-with international school teachers taking ownership of the term due to the international nature of the school and local teachers expressing their deep reservation from the term (Goren \& Yemini, 2016)-it was intriguing to find here that teenagers at the local and international schools articulate very similar (nearly identical) definitions and develop comparable debates over the concept of global citizenship. Apparently, the dominant line of thinking in all focus groups was grounded within the mandatory, clear-cut legal and political definitions of national citizenship, in contrast to the moral and voluntary perceptions of global citizenship. A typical example of (both local and international school) students' thinking in this regard is reflected in the following statement made by a participant in one of the international school focus groups:

I think the main difference between [national] citizenship and global citizenship is that you choose to be a global citizen-it's an individual choice-whereas a [national] citizenship is given to you ... So when it comes to the obligation, it really depends on your own feelings, like how you feel about the world. For example, if you're really passionate about the environment and you identify with global citizenship, you might want to save the world and save the environment from pollution, so this might be your obligation to give the global community something back.

A student at the local school argued the same point, from the local (Israeli) perspective. This student contrasted the need to "pay taxes and serve in the army" (as a national citizenship concept) with the ability to "choose to assist the people in a humanitarian crisis zone ... [as a global citizen,] you choose to play an active role." The integration of both activism and choice within global citizenship is reflected in the words of an international student as well, who 
claimed that "you can decide to be aware of the world ... to be active" (emphasis added). Interestingly, students at both schools ascribe to global citizenship non-obligatory notions.

Notably, moreover, the majority of students in all focus groups at both schools expressed a static, almost apathetic sense of national citizenship, in contrast to the proactive and entrepreneurial nature of global citizenship, which involves "doing something for the world" instead of "just being born somewhere with [a certain] legal status." Despite the students' perception of the voluntary nature of global citizenship, a heated discussion developed in the focus groups at both schools while trying to define global citizenship's inclusion criteria (if any). Students provided conflicting views regarding ones' ability to become a global citizen, ranging from the universalist perspective ("all human beings are global citizens, as they were born in this world," as stated by a student at the local school, representing the views of a minority of students at both schools), through the more dominant line of thinking that was expressed at both schools, maintaining that one must fulfill certain conditions to became a global citizen. For example, students in the international school focus groups stated that global citizenship "is like being able to go to somewhere else and to adapt or understand how other people behave" and it "will not be very effective if you are staying in the same place your entire life and you don't know about other places." Physical mobility as an inclusion criterion was notably more prominent in the views of international students.

Students at both schools expressed recognition of the fact that knowledge of the world is not available to all, because of either financial or geo-political limitations. Students in both schools expressed their passion to engage with the world to change such inequality. Hence, a local student sympathized with those who have no possibility of being

exposed to the world, to everything that is happening in the world .... We are lucky to have such opportunities, we have [access to] news, the media ... in some countries this is not allowed, so you can't really know what is going on, and without knowing, you can't engage and thus be a global [citizen].

Yet according to some, even media exposure and the free availability of information is not enough. As one international school student stated,

in order to be a global citizen you need to be a bit more aware of the world, and I don't think that can be done just through social media or news on TV ... I know that the majority of people cannot afford [other kinds of international exposure] 
... and I do not expect [everyone to travel internationally]. But sometimes even looking around us, we can find someone who comes from another place, we can always find someone who has visited [abroad] and can talk about it.

Other international school students also stressed the need for "exposure to other cultures in order to acquire that global citizenship." One student gave the example of an American living in some mid-western city surrounded only by farmers of the same white ethnicity, never getting to know "what African people look like ... what Asian people look like." This person would never get a "global sense," in this student's words.

The perception of proactivity and agency in the definition of global citizenship, which many scholars advocate (see Andreotti, 2011; Stein, 2015), portrays the global citizen as a person who is willing and able to take action to meet global challenges and to change the existing power relations. Davies (2006) for example, claims that "outrage" must exist, so that motivation for change will be high. Students in our study seem to have adopted this conceptualization, further expressing moral rationalization for global citizenship similar to the one Myers (2011) posits, whereby proactivity is geared by ethical dispositions, expressing liberal-humanist dimensions of GCE.

Clearly, the youth participating in this study relate global citizenship with higher socioeconomic classes and western perceptions of those who can help and those who need the help (although they explicitly deny this notion when asked about it directly), as only those able to travel or to be updated regarding the world can be defined as 'global citizens.' The de-facto exclusion of most of humanity from this debate is not a new feature; in fact, this concern has been widely discussed and often raised in the academic discourse (Andreotti, 2006; Yemini, 2014b). In discussing the elitist common perception of global citizenship in a group discussion, Andreotti (2006: 41) stated: "the group seemed to be unaware that the thought patterns and effects of 'what they love doing' could be directly related to the causes of the problems they were trying to tackle in the first place." The desire of students "to help the poor" is echoing the critical stances towards current GCE models, as elaborated by Andreotti (2011).

The inclusion/exclusion processes are not limited to the global North/South or to the West/the rest conflicts; rather, they are imbedded within the sub-national divides between the haves (mobile, active, and able) and the have-nots (who are excluded). Indeed, one of the students at the local school placed the responsibility for attaining global citizenship on the 
individual him/herself, in stating that: "you must speak languages, visit places, meet cultures." In that sense, both groups of students reflect the 'soft global citizenship' approach that relates such citizenship to 'knowing about the world' and not to 'critical global citizenship' (Andreotti, 2006), which calls for acknowledgement and transformation of hegemonic relations and inequality. Nevertheless students were not keen to adopt the entrepreneurial-neoliberal dimensions of GCE, which were expressed by only two students in the international school. Arshad-Ayaz, Andreotti and Sutherland (2017) claim that "questions such as who is generally considered to be a global citizen, who is not, and how come? might have prompted the youth to identify the systemic and historical imbalances that create the cultural hierarchies at the heart of unequal distributions of wealth, labor, and worth in local and global contexts". In our case students from both schools addressed those questions with a limited level of criticality, remaining within the existing boundaries of Eurocentric power relations while questions of inherited privilege and means of education and global citizenship remained un-touched.

\section{The schools' role and responsibility in fostering global citizenship}

As expected, international school students expressed a high level of confidence in their school's provision of the necessary conditions for fostering global citizenship. They stated that the school's diversity inherently teaches not to judge others' reality in one's own culturallyrelative terms. Studying at an international school "has its advantages of being able to understand a particular issue through the eyes of another person who comes from a different part of the world. That gives you the exposure you need to become a global citizen." Students also noted the school's use of English as an international language and the IB as an international curriculum as advantageous in fostering global citizenship. International students articulated two main characteristics of their school that they believe enable it to provide them with the knowledge and the capabilities of global citizenship: the joint education their school provides to students from different countries and the IB curriculum.

The discourse at the local Israeli school was more complex. At first, local students were challenged to find ways in which their school fosters global citizenship. Ultimately, through the discussions, however, they noted quite a few school initiatives, including curricular content that exposes them to "different worlds and values," classes taken at a university as part of the school curriculum (apparently presenting globally oriented subjects), a particular teacher who 
"presented us with different cultures from his own experience and through stories," the study of English that "will help us in the future," and a "debate group where we discuss issues of global importance." Ultimately, these activities draw a picture that is very similar to that of the international school, except for the implicit use of phrases and terms from the IB curriculum that was inherent in the discourse at the international school.

\section{Diversity and universalism in the Israeli context}

An additional aim of this study involved uncovering how students understand the relationship between national and global citizenship within the unique context of a conflict-ridden society. Bromley (2009: 33) notes that "contemporary cosmopolitanism includes two main emphases, universalism, in the form of global citizenship and human rights, and diversity, in the form of celebrating heterogeneous social groups and promoting equal rights for divergent groups" (emphasis added). Ramirez and Meyer (2012) show how these two trends have been receiving greater attention in social science textbooks worldwide, particularly in Western countries. Here, we adopt the proposed terminology since it was inductively developed through our analysis, revealing that the major axes of conflict in the discussions ignited through the focus groups at both schools involved tensions between universalism and diversity in the definition of the global citizenship concept. As Bromley (2009: 34) states: “[a] common clash occurs when the interests of corporate social groups, such as indigenous groups but also including nation-states, place obligations on members that possibly contradict the universal principles of human rights or limit individual freedoms."

Within this theme, contrary to the first one, we found prominent differences between the perceptions of local versus international school students. Students at both schools were challenged by the desire to pursue universalistic values while engaging diverse groups in global society, and expressed strongly the universalistic nature of global citizenship-including frequent references to human rights and global environmental challenges. International students made statements such as, "global citizenship is to feel part of the world ... emotionally"; and "global citizenship is being aware of the entire world." Local students also stressed the need to place one's global identity ahead of the national one, considering oneself "a human being before an Israeli or Palestinian" or seeing "the human race and not a specific group or nationality." 
However, local Israeli students placed greater emphasis on diversity issues, acknowledging the need to enable the unique rights of minorities and of different religious groups. In contrast, students studying at the international school consider group membership as an individual choice and a source of identity, while placing individual rights above the interests of any particular social group. On the matter of group versus individual rights, the difference between students at the international school versus the local Israeli school emerged quite sharply. For example, an international student explained: "you are first of all a human being...you deserve rights." Expressing a different approach, students at the local school stressed the importance of acting not only on the basis of universal human rights but also in the context of community-based rights: "everybody should be able to pray and live in his/her community according to their own rules, we can't tell other people how to think." Another student at the local school explained: "global citizens are expected to acknowledge that certain groups may have certain values that different from their own, and they [the global citizens] respect these." Those views of the local students may resonate with Stein's (2015) anti-oppressive dimension of GCE, addressing the need to question the existing norms and taboos, since those were historically driven through Euro-centric perspective.

Notably, while we had expected the Israeli-Palestinian conflict (including issues of human rights, war, religion, etc.) to take central stage in the discussions, most of the students' statements were quite neutral in this regard, exhibiting (unintended) avoidance of the IsraeliPalestinian conflict through the global citizenship discourse. "Global citizenship is when your community consists of different people who respect each other ... your nationality doesn't matter; you look at someone's personality and not his religion or nationality." Indeed, they brought examples of issues arising in the US or Europe, despite living in an area in which the tensions inherent to the concept of global citizenship are undeniably strong. Students at both schools avoided the obvious examples related to occupation, the Palestinian state, and the superior status of Jewish citizens within Israel; they were more comfortable discussing these issues as they play out abroad. We will further address this phenomenon in the following section.

\section{The local/international school conflict resolution divide}

As both schools are located in Israel and the international school aims to educate Palestinians and Israelis together with students from the rest of the world as a means for conflict 
resolution, one might envision a conflict-related discourse to take place within the discussion of global citizenship, which in theory might pave educational paths towards conflict resolution (Gill \& Niens, 2014; Reilly \& Niens, 2014; Yamashita, 2006).

Remarkably, statements regarding conflict resolution were absentin the assertions of international school students in particular (perhaps offering some evidence for Hayden's [2011] observations regarding the inadequacy of merely placing together students from different countries in the quest to create global understanding). While students at the local Israeli school discussed the possible transformative impact of global citizenship, students at the international school maintained a highly abstract notion of universalist identification involving a sense of personal comfort with other cultures, to the exclusion of the difficult issues of GCE's potential role in conflict resolution. Thus, ironically perhaps, students at an international school-whose stated mission involves an idealistic gathering of peoples and cultures with a distinct conflictresolution ethos - actually expressed attitudes towards global citizenship that relate less to the conflict-resolution potential of this notion than do the attitudes towards GCE expressed by students at a local Israeli school.

At the end of each focus group, we performed a group exercise asking the students to imagine an ideal world that they can build from the scratch on isolated island somewhere. In presenting their utopian societies, most students at both schools claimed that religion would not exist and that decision-making would be undertaken through a democratic or even Athenian fully participatory model. On their imagined islands, all people are equal, enjoying individual liberties and rights. On those islands, all citizens would be the citizens of the world, and no differences were found in the descriptions produced in international and local schools. One could almost feel the happiness; happiness, indeed, was one of the most frequently used words in the students' descriptions of their ideal society. The statements of students from both schools suggest that GCE might serve as a tool for more equal society (Stein, 2015), but it also might become just another gadget of the privileged (those with the access to the resources, languages and mobilities as was articulated through the discussions in the focus groups), providing tools for happiness only as long as other members of society are willing to find happiness under the same standards and through the same beliefs (Stein, 2015). 


\section{Conclusions}

Global citizenship is a growing field of research, still lacking solid institutional status and a particular definition that would give it shape and meaning (Myers, 2010; Goren \& Yemini, 2017c). Relatively little scholarship has examined empirically the ways in which youth conceptualize and construct actual meanings for global citizenship (some notable exceptions: Arshad-Ayaz, Andreotti, \& Sutherland, 2017; Myers, 2010; Niens \& Reilly, 2012). This study adds an additional layer to the existing discourse not only by providing a glimpse into youth's conceptualization of global citizenship in a conflict-ridden society, but also by offering a unique angle comparing between schools in Israel working in different educational contexts. Table 1 summarizes the main findings in our study, comparing between the perceptions of students at an international and a local school, in reference to the key scholarship in the area.

We found that in general, students from both schools perceive of and define global citizenship similarly - in contrast to very different articulations of global citizenship found among teachers at local and international schools in Israel (Goren \& Yemini, 2016; 2017a) and in contrast to the curricula they are exposed to (not existing in local school and highly profiled in the international school). Quite likely, the similarity in students' views across the two schools results from the similar lifestyle of 'global youth'; indeed, their experiences and perceptions are formed on the basis of socio-economic status more than nationality, religion, or political stance. With the student populations of both schools in this study representing similarly privileged socio-economic backgrounds, their similar opinions in this regard only serve to sharpen the supremacy of socio-economic affiliation over national identity in such matters (Jimenez, Lerch, \& Bromley, 2017). While international school students are more commonly considered 'global elites' than are students at local schools, other studies have documented similarities in student perceptions at local schools catering to privileged populations and at international schools in other countries, for example in Australia, Singapore, and Canada (Doherty, 2009; Koh \& Chong, 2014; Maxwell \& Aggleton, 2016; Tarc \& Tarc, 2015, respectively). While teachers at local schools (in contrast to those at international schools) are still living their in-school, curricularbased reality (Goren \& Yemini, 2016), youth at local schools are exposed to the world through other means outside the school, thus shaping their perceptions and knowledge; seemingly, this tendency will grow in years to come. As such, the in-school preparation of global citizenship that is purely rationalized by an international audience and an IB curriculum rather than bounded to 
specific dispositions (as per Andreotti, Biesta, \& Ahenakew, 2015) may be inadequate, as student views uncovered in this study demonstrate. With the tremendous growth of the IB sector in state schools around the world (Resnik, 2016), this study questions the use of IB curricula for GCE education, especially such education that goes beyond the common Eurocentric and neoliberal notions of the concept.

Seemingly, students from both schools present very similar views regarding the definition of global citizenship and share similar (albeit not identical) perceptions on such citizenship's inclusion criteria. Both groups of students applied extremely Western, Eurocentric terminology (e.g., "freedom to choose" and "individual rights"), absent any awareness of how such discourse reaffirms existing power relations (Andreotti, 2014; Stein, 2015). The students base their definitions of GCE on entrepreneurial and liberal-humanist dimensions (Stein, 2015). The differences were found in the importance students at each of the schools attribute to each of the two major ingredients of cosmopolitan outlook: universalism and diversity (Bromley, 2009). Students at the local school were found to attribute high importance not only to universalism but also to diversity and the transformative potential of cross-cultural understanding through global citizenship, while students at the international school assessed universalism to be of much higher potency than diversity in the quest for global citizenship. Indeed, students at the local school seemed to express more broadly the more complex and inclusive elements of global citizenship than did those at the international school. Possibly in contrast to the common logic, students at the local school seemed much more aware of and dedicated to the anti-oppressive nature of the GCE and to some extend expressed the desire to engage with the current situation. Students at the local school also seemed more cognizant of the transformative potential of GCE as well of the hegemonic nature of GCE (Stein, 2015). Indeed, these students raised issues related to diversity and self-definition rights more, stressing minority rights to a much greater extent than students at the international school.

Despite the Israeli-Palestinian conflict's intractable nature and the violence the region experienced in the summer of 2014 (just two months prior to the focus group discussions held in this study), the Israeli-Palestinian conflict (and its potential resolution) was altogether absent from the discourse of not only local but also international school students - even in focus groups at the international school that included Palestinian and Israeli students working together to define and conceptualize the term 'global citizenship.' The absence of conflict in students' 
discourse reinforces the need for development of specific measures to tackle conflict resolution and peace education in conflict-related education contexts. As GCE became one of the official education goals through the UNESCO sustainable development goals, it may be incorporated within the schools' realm in the next years. This study provides some logic into the perceptions of students, logic that should be taken into account while further developing or implementing this concept.

Given the evolving nature of society and the mobility brought on by globalization, as well as the new skills required of citizens who wish to participate and compete in a globalized society, it is important to explore how students in different contexts perceive the evolving concept of GCE. We show that students that from both schools perceive global citizenship quite differently from how GCE is articulated by teachers in those two different contexts. Moreover, we problematize the paradigmatic notion of GCE as it being delivered in International Baccalaureate curricula and we question the proposed role of GCE in conflict resolution. Insights from this empirical comparative study of adolescents' thinking can help to guide the academic discourse and practical curriculum development processes regarding the complexity of citizenship and identification in a global age. We also offer a valuable contribution for curriculum developers and teachers at international schools, presenting a nuanced and detailed analysis of students' perceptions there with respect to the commonly perceived inherent nature of global citizenship at such schools. 
Table 1: Schematic summary

\begin{tabular}{|c|c|c|c|}
\hline & $\begin{array}{lr}\text { Perceptions } & \text { of } \\
\text { international } & \text { school } \\
\text { students } & \\
\end{array}$ & $\begin{array}{l}\text { Perceptions of local } \\
\text { school students }\end{array}$ & $\begin{array}{l}\text { Relations to current } \\
\text { scholarship vs. our study }\end{array}$ \\
\hline $\begin{array}{l}\text { Who can be a global } \\
\text { citizen? }\end{array}$ & \multicolumn{2}{|c|}{$\begin{array}{l}\text { Similar for both schools: Voluntary moral } \\
\text { commitment available to individuals with } \\
\text { certain resources (mobile, access to the } \\
\text { 'other') }\end{array}$} & $\begin{array}{l}\text { In both schools colonial } \\
\text { and } \\
\text { perceptions of GCE were } \\
\text { found (Andreotti, 2006; } \\
\text { Myers, 2006; 2010; } \\
\text { Myers \& Zaman, } \\
\text { 2009;Stein, 2015) }\end{array}$ \\
\hline $\begin{array}{ll}\text { Tensions } & \text { in } \\
\text { definition } & \end{array}$ & $\begin{array}{l}\text { Universalistic }- \\
\text { individual over group }\end{array}$ & $\begin{array}{l}\text { Diversity }- \text { group } \\
\text { equal to individual }\end{array}$ & $\begin{array}{l}\text { We show empirically the } \\
\text { tension and the different } \\
\text { emphasis among students } \\
\text { from each of the schools. } \\
\text { Cosmopolitanism as a } \\
\text { spectrum of universality } \\
\text { and diversity } \\
\text { (Bromley, 2009) - }\end{array}$ \\
\hline $\begin{array}{l}\text { The role of schools } \\
\text { in developing global } \\
\text { citizenship }\end{array}$ & $\begin{array}{l}\text { Clear understanding } \\
\text { of GCE but } \\
\text { conceptualized as a } \\
\text { direct consequence } \\
\text { of international } \\
\text { student body and IB } \\
\text { curriculum }\end{array}$ & $\begin{array}{l}\text { Initially unclear } \\
\text { understanding of } \\
\text { GCE, but following } \\
\text { authors' explanations } \\
\text { articulated in } \\
\text { concrete terms } \\
\text { (studying languages } \\
\text { and cultures, } \\
\text { practicing advocacy, } \\
\text { environmental } \\
\text { activism facilitated } \\
\text { by the school) }\end{array}$ & $\begin{array}{l}\text { Teachers' agency. We } \\
\text { propose to address socio- } \\
\text { economic issues as } \\
\text { potential gaps when } \\
\text { educating towards global } \\
\text { citizenship } \\
\text { (as per Authors, 2016; } \\
\text { Schweisfurth, 2006) }\end{array}$ \\
\hline $\begin{array}{l}\text { Global Citizenship } \\
\text { Education as a tool } \\
\text { for } \quad \text { conflict } \\
\text { resolution }\end{array}$ & $\begin{array}{l}\text { Similar for both schoo } \\
\text { Almost absent from the }\end{array}$ & discussion & $\begin{array}{l}\text { GCE can serve as a tool } \\
\text { for conflict resolution, } \\
\text { but the connection should } \\
\text { be explicit and intentional } \\
\text { for such an endeavor to } \\
\text { succeed } \\
\text { (Davies, 2006; Gill \& } \\
\text { Niens, 2014; Reilly \& } \\
\text { Niens, 2014) }\end{array}$ \\
\hline
\end{tabular}




\section{References}

Alexander, H. A., Pinson, H., \& Yonah, Y. (Eds.), (2012). Citizenship, education and social conflict: Israeli political education in global perspective. New York, NY: Routledge.

Anderson, B. (1991). Imagined communities. London and New York: Verso.

Andreotti, V. (2006). Soft versus critical global citizenship education. Policy \& Practice-A Development Education Review, 3, 40-51.

Andreotti, V. (2010). Postcolonial and post-critical 'global citizenship education'. In G. Elliott, C. Fourali \& S. Issler, (Eds.), Education and Social Change: Connecting local and global perspectives, (pp. 238-250). London, UK: Continuum International Publishing Group.

Andreotti, V. (2011). (Towards) decoloniality and diversality in global citizenship education. Globalisation, Societies and Education, 9(3-4), 381-397.

Andreotti, V. (2014). Soft versus critical global citizenship education. In S. McCloskey (Ed.), Development education in policy and practice (pp. 21-31). Palgrave Macmillan UK.

Andreotti, V., Biesta, G., \& Ahenakew, C. (2015). Between the nation and the globe: education for global mindedness in Finland. Globalisation, Societies and Education, 13(2), 246-259.

Arshad-Ayaz, A., Andreotti, V., \& Sutherland, A. (2017). A critical reading of The National Youth White Paper on Global Citizenship: What are youth saying and what is missing?. International Journal of Development Education and Global Learning, 8(2), 19-36.

Avnon, D. (2013). Research and policy in citizenship education within the secondary school system in Israel. Jerusalem: Israeli Society of National Studies (Hebrew).

Banks, J. A. (2008). Diversity, group identity, and citizenship education in a global age. Educational Researcher, 37(3), 129-139.

Bar-Tal, D. (2000). From intractable conflict through conflict resolution to reconciliation: Psychological analysis. Political Psychology, 21(2), 351-365.

Bates, R. (2012). Is global citizenship possible, and can international schools provide it? Journal of Research in International Education, 11(3), 262-274.

Bloor, M., Frankland, J., Thomas, M., \& Robson, K. (2001). Focus Group in Social Research. London: Sage.

Bowden, B. (2003). The perils of global citizenship. Citizenship Studies, 7(3), 349-362.

Bromley, P. (2009). Cosmopolitanism in Civic Education: Exploring Cross-National Trends, 1970-2008. Current Issues in Comparative Education, 12(1), 33-44.

Brunold-Conesa, C. (2010). International education: The International Baccalaureate, Montessori and global citizenship. Journal of Research in international Education, 9(3), 259-272.

Cohen, A. (2017). Between teachers' perceptions and civic conceptions: lessons from three Israeli civics teachers. Journal of Curriculum Studies, 49(4), 542-560.

Creswell, J. W. (2007). Qualitative enquiry and research design: Choosing among five approaches. Thousand Oaks: Sage publications.

Davies, L. (2006) Global citizenship: abstraction or framework for action? Educational Review, 58(1), 5-25.

Davies, L. (2008). Interruptive democracy in education. In J. Zajda, L. Davies \& S. Majhanovich (Eds.), Comparative and Global Pedagogies. (pp.15-31). Netherlands: Springer.

Dill, J. S. (2013). The longings and limits of global citizenship education: The moral pedagogy of schooling in a cosmopolitan age. New York, NY: Routledge. 
Doherty, C. (2009). The appeal of the International Baccalaureate in Australia's educational market: A curriculum of choice for mobile futures. Discourse: Studies in the cultural politics of education, 30(1), 73-89.

Fren, E. F. (2001). Advanced focus group research. Thousand Oaks, California: Sage.

Gaskell, G. (2011). Chapter 3: Individual and group interviews. In: M. W. Bauer \& G. Gaskell (Eds.), Qualitative Researching with Text, Image and Sound (pp. 49-68). Raanana: The Open University of Israel.

Gardner-McTaggart, A. (2016). International elite, or global citizens? Equity, distinction and power: the International Baccalaureate and the rise of the South. Globalisation, Societies and Education, 14(1), 1-29.

Gaudelli, W. (2016). Global Citizenship Education: Everyday Transcendence. New York: Routledge.

Gearon, L. (2016). Global Human Rights. In A. Peterson, R. Hattam, M. Zembylas \& J. Arthur (Eds.), The Palgrave International Handbook of Education for Citizenship and Social Justice. (pp. 205-228). London: Palgrave Macmillan.

Gill, S., \& Niens, U. (2014). Education as humanisation: dialogic pedagogy in post-conflict peacebuilding. Compare: A Journal of Comparative and International Education, 44(1), 1-9.

Glaser, B. G., \& Strauss, A. (1967). The discovery of ground theory. New York: Alpine.

Goren, H., \& Yemini, M. (2016). Global citizenship education in context: Teacher perceptions at an international school and a local Israeli school. Compare: A Journal of Comparative and International Education, 46(5), 832-853.

Goren, H., \& Yemini, M. (2017a). Obstacles and opportunities for global citizenship education under intractable conflict: the case of Israel. Compare: A Journal of Comparative and International Education, 1-17.

Goren, H., \& Yemini, M. (2017b). Citizenship education redefined-A systematic review of empirical studies on global citizenship education. International Journal of Educational Research, 82, 170-183.

Goren, H., \& Yemini, M. (2017). The global citizenship education gap: Teacher perceptions of the relationship between global citizenship education and students' socio-economic status. Teaching and Teacher Education, 67, 9-22.

Hanna, H. (2015). Dealing with difference in the divided educational context: Balancing freedom of expression and non-discrimination in Northern Ireland and Israel. Compare: A Journal of Comparative and International Education, 1-15.

Hayden, M. (2011). Transnational spaces of education: the growth of the international school sector. Globalisation, Societies and Education, 9(2), 211-224.

Hayden, M.C., \& Wong, C. S. (1997). The International Baccalaureate: International education and cultural preservation. Educational Studies, 23(3), 349-361.

Harpaz, Y. (2013). Rooted cosmopolitans: Israelis with a European passport-History, property, identity. International Migration Review, 47(1), 166-206.

Ichilov, O., Salomon, G., \& Inbar, D. (2005). Citizenship Education in Israel-A JewishDemocratic State. Israel Affairs, 11(2), 303-323.

Jimenez, J.D., Lerch, J., \& Bromley, P. (2017). Education for global citizenship and sustainable development in social science textbooks. European Journal of Education. Ahead of Print.

Koh, A., \& Chong, T. (2014). Education in the global city: the manufacturing of education in Singapore. Discourse: Studies in the Cultural Politics of Education, 35(5), 625-636. 
Marshall, C., \& Rossman, G. B. (2014). Designing qualitative research. Thousand Oaks: Sage publications.

Maxwell, C., \& Aggleton, P. (2016). Creating cosmopolitan subjects: The role of families and private schools in England. Sociology, 50(4), 780-795.

Miles, M. B., \& Huberman, A. M. (1994). Qualitative data analysis: A sourcebook. Thousand Oaks: Sage Publications.

Monaghan, C., \& Spreen, C. A. (2016). From Human Rights to Global Citizenship Education: Movement, Migration, Conflict and Capitalism in the Classroom. In J. Zajda \& S. Ozdowski (Eds.), Globalisation, Human Rights Education and Reforms, (pp. 35-53). Dordrecht: Springer.

Myers, J. P. (2006). Rethinking the social studies curriculum in the context of globalization: Education for global citizenship in the US. Theory \& Research in Social Education, 34(3), 370394.

Myers, J. P. (2010). 'To benefit the world by whatever means possible': adolescents' constructed meanings for global citizenship. British Educational Research Journal, 36(3), 483-502.

Myers, J. P. (2016). Charting a democratic course for global citizenship education: Research directions and current challenges. Education Policy Analysis Archives 24(2016), 1-19.

Myers, J., \& Zaman, H. (2009). Negotiating the global and national: Immigrant and dominantculture adolescents' vocabularies of citizenship in a transnational world. The Teachers College Record, 111(11), 2589-2625.

Nasser, R., \& Nasser, I. (2008). Textbooks as a vehicle for segregation and domination: state efforts to shape Palestinian Israelis' identities as citizens. Journal of Curriculum Studies, 40(5), 627-650.

Neuberger, B. (2007). Education for democracy in Israel: Structural impediments and basic dilemmas. International Journal of Educational Development, 27(3), 292-305.

Niens, U. \& Chastenay, M. H. (2008). Educating for peace? Citizenship education in Quebec and Northern Ireland. Comparative Education Review, 52(4), 519-540.

Niens, U., O'Connor, U., \& Smith, A. (2013). Citizenship education in divided societies: teachers' perspectives in Northern Ireland. Citizenship Studies, 17(1), 128-141.

Niens, U. \& Reilly, J. (2012). Education for global citizenship in a divided society? Young people's views and experiences. Comparative Education, 48(1), 103-118.

Nussbaum, M. (1994). Patriotism and cosmopolitanism. Boston Review, XIX (5), 3-16.

Osler, A. \& Starkey, H. (2003) Learning for cosmopolitan citizenship: theoretical debates and young people's experiences. Educational Review, 55(3), 243-254.

Oxley, L. \& Morris, P. (2013). Global citizenship: A typology for distinguishing its multiple conceptions. British Journal of Educational Studies, 61(3), 301-325.

Pinson, H. (2007). Inclusive curriculum? Challenges to the role of civic education in a Jewish and democratic state. Curriculum Inquiry, 37(4), 351-382.

Puchta, C., \& Potter, J. (2004). Focus Group Practice. London: Sage.

Quaynor, L. (2015). 'I do not have the means to speak:'educating youth for citizenship in postconflict Liberia. Journal of Peace Education, 12(1), 15-36.

Ramirez, F. O., \& Meyer, J. W. (2012). Toward post-national societies and global citizenship. Multicultural Education Review, 4(1), 1-28.

Rapoport, A. (2010). We cannot teach what we don't know: Indiana teachers talk about GCE. Education, Citizenship and Social Justice, 5(3), 179-190. 
Reilly, J., \& Niens, U. (2014). Global citizenship as education for peacebuilding in a divided society: structural and contextual constraints on the development of critical dialogic discourse in schools. Compare: A Journal of Comparative and International Education, 44(1), 53-76.

Resnik, J. (2016). Struggling for recognition: access to higher education through the International Baccalaureate. Critical Studies in Education, 1-18.

Roman, L. G. (2003). Education and the contested meanings of 'global citizenship'. Journal of educational change, 4(3), 269-293.

Schattle, H. (2008). Education for global citizenship: Illustrations of ideological pluralism and adaptation. Journal of Political Ideologies, 13(1), 73-94.

Schweisfurth, M. (2006). Education for global citizenship: Teacher agency and curricular structure in Ontario schools. Educational Review, 58(1), 41-50.

Stein, S. (2015). Mapping global citizenship. Journal of College and Character, 16(4), 242-252. Tamatea, L., Hardy, J., \& Ninnes, P. (2008). Paradoxical inscriptions of global subjects: critical discourse analysis of international schools' websites in the Asia-Pacific Region. Critical Studies in Education, 49(2), 157-170.

Tarc, P. \& Tarc, A.M. (2015). Elite international schools in the Global South: transnational space, class relationalities and the 'middling'international schoolteacher. British Journal of Sociology of Education, 36(1), 34-52.

Veugelers, W. (2011). The moral and the political in global citizenship: Appreciating differences in education. Globalisation, Societies and Education, 9(3-4), 473-485.

UNESCO. (2014). Global Citizenship Education: Preparing Learners for the Challenges of the 21st Century. 345. Paris: UNESCO: Education Sector.

Yamashita, H. (2006). Global citizenship education and war: The needs of teachers and learners. Educational Review, 58(1), 27-39.

Yemini, M. (2014a). Internationalization of Secondary Education-Lessons From Israeli Palestinian-Arab Schools in Tel Aviv-Jaffa. Urban Education, 49(5), 471-498.

Yemini, M. (2014b). Internationalisation discourse What remains to be said?. Perspectives: Policy and Practice in Higher Education, 18(2), 66-71.

Yemini, M. (2015). Internationalisation discourse hits the tipping point: A new definition is needed. Perspectives: Policy and Practice in Higher Education, 19(1), 19-22.

Yemini, M., Bar-Nissan, H., \& Yardeni, O. (2014). Between "us" and "them": Teachers' perceptions of the national versus international composition of the Israeli history curriculum. Teaching and Teacher Education, 42, 11-22.

Yemini, M., \& Dvir, Y. (2016). International Baccalaureate as a litmus test revealing conflicting values and power relations in the Israeli education system. Discourse: Studies in the Cultural Politics of Education, 37(2), 310-323.

Yemini, M., \& Giladi, A. (2015). Internationalization motivations and strategies of Israeli educational administration programs. Journal of Studies in International Education, 19(5), 423440.

Yemini, M., \& Fulop, A. (2015). The international, global and intercultural dimensions in schools: an analysis of four internationalised Israeli schools. Globalisation, Societies and Education, 13(4), 528-552. 